は会誌印刷費が会費收入を上回っているので，1〜2年後には会費值上げをしなければなら なくなる。それで，今後論文の龱版製版代と超過頁（報文は 6 印刷頁，短報は 2 頁印刷頁を こえた頁）の製版代を著者負担とすることが了承された。また会の収人を増すため会員の増 加や，賛助会員を作ることなども検討した。次回大会の開催地についても論じた。

昭和57年度総会 昭和 57 年 11 月 14 日（日）午後 1 時 1 時 40 分, 東京学芸大学教育工学教室。 第21回大会の当日，午後の一般講演に先立って，原幸治氏を議長として運営された。庶務 ・会計・編集の各幹事から業務報告がありこれを承認した。会計報告は年度が終了し監查を 受けてから次号会誌登載する。

現在の学会会計の状況から今後投稿論文の図版の製版代と超過頁（報文は 6 印刷頁，短報 は 2 頁印刷頁をこえた頁）の製版代とを著者負担とすることになった（投稿規定第 4 項参 照)。賛助会員制についても論議がなされ，来年度に会則を改正してこの制度を新設したい といらことになった。この他，有志の会員に広く寄付を打願いすることになった。 来年度の大会は京都大学で開催されることとなった。

\title{
雑報
}

SSAR-HL 大会に参加して

深比祝

旧知の Dr. Kraig Adler から「来年は SSAR (Society for the Study of Amphibians and Reptiles) の第25回記念大全が開かれるので是非出席されたい, Mountain Lake(第11回 
大会開催地）以来の旧交を温めたい」との便りがあったのは，1981年 2 月のことであった。今 年（1982年）1月に SSAR 会長 Kraig Adler 名で「1982年 8 月 1 日〜 6 日 North Carolina 州 Raleigh で開くSSAR 第25回記念大会に，貴学会の公式代表として貴兄に出席して頂きた い。この大会には諸外国の学会代表も多数出席される予定である。もし差支えあるときは代理 の方（単数又は複数）をご指名頂きたい」との公式書簡を受取った。このとき私は体調がすぐ れず，とても旅行出来る状態ではなかったので幹事の方数名に相談し，ゴリス氏がこの大会に 出席して下さることとなった。4月になり私の体調は恢復し，私も出席したくなり，結局我々 2 名が出席することになった。

SSAR 大会はHL (Herpetologists’ League) 大会と合同で開かれ枚式には“25th Annual Meeting SSAR - 30th Annual Meeting HL”といら。大会は Raleigh 市西端の Meredith College で開かれ，宿舎はその構内の学生寮があてられた。

大会は 8 月 1 日から始まったが, 当日は登録手続や役員会などで, 一般は次の 2 日からであ る。2 日は朝 8 時から大ホールで開会式があり, SSAR 会長 Dr. Adler の挨拶のとき集まっ た15ケ国代表が次々と紹介された。その後，HL 会長 Dr. Inger の挨拶があった。午前10時 からは3つの会場に分れ講演が始まった。らち 1 会場は 4 日間を通して爬虫類雨生類の分子的 ・ゲノム的進化のシンホジウムに, 他の 2 会場では一般講演が計 150 題注ど発表された。一般 講演は発表12分質疑 3 分計15分間，座長は時計係をも兼ね，スライド係にはボランチアの年芘 の婦人方が多くみられた。スライド映写機はコダック社カルーセル型が用いられていた。

今回は第25回記念大会といらことで特に出席者が多かったといらことである。毎日夕方や夜 には备種の会合や行事がぎっしりと組まれていた。我々の関係したものは 2 日夕 5 時からの International Herpetological Congress Planning Committee があった。15ケ国（米国を 含む）の代表33名が集まり，今後国際的な会議を鬥くことについて話し合った。そうして Dr. Adler を委員長として今後の計画を立てるといらことになった。

Raleigh は森林に包まれた美しい町で，会場となった Meredith College も緑の芝生と大 樹にかこまれた落ち着いた広々とした大学である。わがゴリス氏は多くの知己にかこまれ，連 日大活躍しておられた。私も以前渡米したときお世話になった多くの方々と再会でき，州に又 新しい知己を得てたのしい1週間であった。なお，我々の大会出席は学会代表として招待され たとはいえ，費用は全額私費支弁である。

\section{SSAR-HL 大会に参加して}

R. コ V

1982年 8 月 1 6 日に本会会長深田祝先生といっしょにSSAR (Society for the Study of Amphibians and Reptiles) と HL (Herpetologists' League) が共催した大会に参加した。 本大会はHLにとっては第30回，SSARにとっては第25回（いわゆる銀婚式）であっただけ に, 参加者は600人を上回り, アメリカ史上最大の爬虫類学者の集まりとなった。

アメリカの学者の他に, SSAR の招待で, オーストラリア, カナダ, 英国, フランス, イン ド,イタリア, 日本, オランダ, ニュージランド, ホーランド, ブェルトリュ, 南ア連邦, 韓 国及び西ドイッから，ひとりわ至数名の代表者も参加した。これら外国代表者参加の目的は SSAR の25周年を祝うと同時に，か礼てからヨーロッパなどで懸案となっている国際的爬虫 